\title{
ÁREAS DE PRESERVAÇÃO PERMANENTE NO ENTORNO DE NASCENTES: CONFLITOS, LACUNAS E ALTERNATIVAS DA LEGISLAÇÃO AMBIENTAL BRASILEIRA
}

\author{
PERMANENT PRESERVATION AREAS AROUND RIVER'S SPRINGS: \\ CONFLICTS, GAPS AND ALTERNATIVES IN THE BRAZILIAN \\ ENVIRONMENTAL LAW
}

\section{LA LÉGISLATION SUR LES UNITÉS DE PRESERVATION PERMANENTE AUTOUR DE SOURCES D`EAU AU BRÉSIL: LES CONFLICTS, LES LACUNES ET LES ALTERNATIVES}

\author{
Laila Gonçalves do Carmo - Universidade Federal de Minas Gerais - Belo Horizonte - Minas Gerais - Brasil \\ lailagcarmo@gmail.com \\ Miguel Fernandes Felippe - Universidade Federal de Juiz de Fora - Juiz de Fora - Minas Gerais - Brasil \\ mffelippe@gmail.com
}

\begin{abstract}
Antônio Pereira Magalhães Junior - Universidade Federal de Minas Gerais - Belo Horizonte - Minas Gerais - Brasil magalhaesufmg@yahoo.com.br
\end{abstract}

\section{Resumo}

Este trabalho versa sobre as implicações da legislação ambiental sobre as Áreas de Preservação Permanente (APP) das nascentes dos cursos d'água. 0 objetivo geral é apontar e discutir as dificuldades na identificação e no mapeamento das APP de nascentes, tendo em vista a sua complexidade fisiográfica, dinâmica e tipológica. Foram elaboradas propostas de mapeamento de nascentes com características de intermitência, mobilidade e exfiltração difusa, além de uma nascente pontual e perene, que se aproxima do modelo idealizado tanto pela legislação quanto pelo senso comum. As nascentes selecionadas estão localizadas nos municípios de Belo Horizonte e Jaboticatubas, na porção central de Minas Gerais. As reflexões aqui realizadas indicam a necessidade de aproximação da legislação à realidade prática das nascentes, fundamentada no atual estágio de conhecimento científico sobre esses sistemas.

Palavras-chave: nascentes, Áreas de Preservação Permanente, exfiltração, Código Florestal.

\section{Abstract}

This article discusses the implications of the Brazilian legislation about the permanent preservation areas (Áreas de Preservação Permanente - APP) around river's springs. Thereby, this work aims to point and discuss the difficulties in the identification and mapping of springs' APP, due to the weakness of the law and the complexity of these environmental systems. It was proposed some guidelines for mapping the APP of springs characterized by intermittence, mobility or diffuse exfiltration. Nevertheless, one typical spring with punctual and perennial exfiltration, that represents the idealistic model present on the legislation, was included in the study. These springs are located on central portion of Minas Gerais state, in the municipalities Belo Horizonte and Jaboticatubas. The results demonstrate the necessity of dialog between the scientific knowledge, the technical methods and the environmental law to improve the protection of springs in Brazil.

Key words: spring, permanent preservation areas, exfiltration water, environmental law. 


\section{Résumé}

L'article discute les implications de la législación sur l'environnement dans les unités de préservation permanente (Áreas de Preservação Permanente - APP) autour des sources d'eau. L'objectif général est donc de signaler et de discuter des difficultés dans I'identification et cartographie de ce genre de APP tenant en vue sa complexité physiographique, dynamique et typologique. Des alternatives de cartographie de APP de sources d'eau ont été proposées concernant les caracteristiques de l'intermittence, mobilité et presence de l'exfiltration diffuse. II a été aussi étudié une source d'eau du type ponctuel et pérenne que s'approche du modèle idéalizé par la législation et par le sens générale de la société. Les sources d’eau étudiées se situent dans les municipalités de Belo Horizonte et Jaboticatubas, région centrale de I'État du Minas Gerais. Les réflexions réalizées soulignent la nécessité d'un rapprochement de la législation à la réalité concrete des sources d'eau a partir de l'état actuel de connaissances scientifiques sur ces systèmes.

Mots-clés: sources d'eau, unités de préservation permanente, exfiltration d'eau, legislation sur l'environment.

\section{Introdução}

A legislação ambiental brasileira possui nítida preocupação de manutenção dos recursos hídricos, faunísticos e florísticos, elencando elementos prioritários para proteção, como feições geomorfológicas (topos de morro, nascentes e margens fluviais, entre outras). Contudo, no que tange às nascentes, existem lacunas nos documentos legais que dificultam e até impossibilitam a aplicação prática de mecanismos de proteção, em virtude da falta de articulação com a produção científica.

As nascentes são sistemas ambientais naturais em que ocorre a exfiltração da água subterrânea de modo temporário ou perene, formando canais de drenagem a jusante (Felippe, 2009). São caracterizadas, fisiograficamente, por feições geomorfológicas ou estruturas geológicas que iniciam a drenagem superficial em canais de primeira ordem.

Como as nascentes, por um lado, são elementos essenciais do ciclo hidrológico e vitais para o ser humano e seu desenvolvimento cultural, econômico e tecnológico, a relevância da sua proteção é evidenciada pelos marcos legais brasileiros. Por outro lado, a singularidade desses sistemas é foco de controvérsias na práxis da legislação ambiental, em parte devido ao desconhecimento de suas heterogeneidades, e em parte devido à sobreposição de interesses econômicos, sobretudo do setor imobiliário. Contudo, Valente e Gomes (2005, p. 147) atentam para o fato de que "a nascente é um fenômeno natural que transcende o ponto onde se manifesta, sendo resultado de um processo hidrológico que ocorre em uma área de contribuição chamada bacia hidrográfica”.

Em razão da grande heterogeneidade das nascentes, quanto a fatores tipológicos, seu diagnóstico deve abarcar, entre outros parâmetros, a 
morfologia (feição do relevo na escala de campo na qual ocorre a surgência), o tipo de exfiltração (nascentes pontuais, difusas ou múltiplas) e, ainda, a mobilidade do local de exfiltração (nascentes fixas ou móveis) e a sazonalidade (nascentes perenes, intermitentes ou efêmeras), conforme já exposto por Springer e Stevens, 2009; Felippe et al., 2009; Faria, 1997; e Valente e Gomes, 2005. Essas características são resultantes do contexto ambiental regional e local no qual as nascentes estão inseridas e seu reconhecimento parte da experiência de campo. Logo, muitas dessas características não são consideradas pela legislação em vigor. Para Neves et al. (2009), a Geomorfologia possui postulados teóricos consagrados quanto à sua utilização por especialistas; entretanto, carece de maior discussão e clareza na ocasião de seu uso na legislação ambiental.

$\mathrm{Na}$ prática, por um lado, a carência de conhecimento científico sobre as nascentes, no momento de elaboração de textos legais, incorre na delimitação de Áreas de Preservação Permanente (APP), muitas vezes não eficiente quanto aos reais objetivos de proteção idealizados na legislação. Por outro lado, a legislação também possui elementos que, se corretamente interpretados, favoreceriam uma proteção mais eficaz do que o corriqueiro "raio de 50 m", propalado tanto pela Lei Federal n. 4.771, de 15/9/1965, quanto pela Lei Federal n. 12.651, de 25/5/2012. Este é o caso das bacias de contribuição, previstas na Resolução n. 303/2002 do Conselho Nacional do Meio Ambiente (CONAMA), que abrangem, em geral, uma maior extensão areal do que as APP e que são frequentemente ignoradas nos mapeamentos referentes aos licenciamentos ambientais.

Tendo como panorama motivador as lacunas e contradições do quadro legal brasileiro referente à proteção das nascentes, o objetivo deste trabalho é apontar e discutir as dificuldades na identificação e no mapeamento das APP de nascentes, tendo em vista a sua complexidade fisiográfica, dinâmica e tipológica. Foram elaboradas propostas de mapeamento de nascentes com características de intermitência, mobilidade e exfiltração difusa, além de uma nascente pontual e perene (que se aproxima do modelo idealizado tanto pela legislação quanto pelo senso comum). As nascentes selecionadas estão localizadas nos municípios de Belo Horizonte e Jaboticatubas, na porção central de Minas Gerais.

Três dos principais problemas de mapeamento identificados foram discutidos com base nos conceitos acadêmicos e legais, ilustrando a realidade prática desses desafios. Apresentaram-se as possibilidades e 
impossibilidades de cada abordagem. Os resultados da pesquisa podem contribuir para as reflexões e iniciativas de proteção de nascentes no âmbito das políticas ambientais e de recursos hídricos em nível federal, estadual e municipal. Processos de informação, reflexão e discussão sobre o papel ambiental das nascentes são ainda mais relevantes quando interesses diversos surgem como entraves à sua proteção. Referindo-se ao chamado "Movimento Antiecológico", no Congresso Nacional, Accioly e Sánchez (2012) afirmam que esses grupos e indivíduos são movidos por interesses de grupos privados e possuem suas próprias estratégias argumentativas. Dentre elas, os autores destacam a desinformação, a distorção de descobertas científicas e a pressão em favor da flexibilização da legislação ambiental.

\section{Procedimentos metodológicos}

O trabalho foi baseado na representação cartográfica das APP de nascentes em razão de suas características ambientais. Inicialmente, realizou-se o levantamento de trabalhos científicos e normas legais considerados de maior relevância para a temática. Concomitantemente, foram selecionadas as unidades de estudo que ilustrassem as dificuldades de mapeamento mais frequentes (mobilidade, intermitência e exfiltração difusa). Os dados cartográficos e de campo (como localização, características das nascentes e fotografias) foram selecionados e organizados, com o intuito de gerar informação cartográfica para a discussão das possibilidades de mapeamento das APP.

Os problemas e desafios concernentes ao foco do trabalho suscitam reflexões sobre a eficácia dos processos de proteção, conservação e gestão das nascentes nacionalmente, estabelecendo um paralelo entre o conhecimento científico, a legislação e sua práxis.

Para selecionar as unidades de estudo, recorreu-se ao banco de dados do Grupo de Pesquisa em Geomorfologia e Recursos Hídricos, do Instituto de Geociências (IGC) da Universidade Federal de Minas Gerais (UFMG), constituído de aproximadamente 150 nascentes mapeadas e caracterizadas desde 2008 .

As nascentes foram selecionadas de maneira a retratar a diversidade e realidade de aquíferos livres no domínio tropical úmido e subúmido. Assim, as principais dificuldades de interpretação e execução da legisla- 
ção são ilustradas, visto que a heterogeneidade de condições geológicas e ambientais nas quais ocorrem nascentes não é contemplada pelos textos legais. Foram selecionadas as seguintes nascentes: 1) SC24: localizada no Parque Nacional da Serra do Cipó (Jaboticatubas-MG) - apresenta exfiltração múltipla e mobilidade superior a 1,5km; 2) N065: localizada no Parque Lagoa do Nado (Belo Horizonte-MG) - é caracterizada por exfiltração difusa; 3) N018: localizada no Parque das Mangabeiras (Belo Horizonte-MG) - é pontual e intermitente; e 4) N005: também localizada no Parque das Mangabeiras - é perene e pontual, representando o padrão idealizado pela legislação.

Uma atenção especial deve ser dada à sazonalidade na ocasião da identificação das nascentes. Por isso, os trabalhos de campo, para o estudo de N018, N005, N065, abrangeram as estações úmida e seca em 2008 e 2009, de acordo com o balanço hídrico verificado para as áreas de estudo (Felippe, 2009). A nascente SC24 foi monitorada mensalmente (entre março de 2011 e março de 2012), fornecendo uma maior quantidade de dados empíricos que respaldam a sua característica de mobilidade.

O mapeamento das APP foi realizado com base nos princípios da legislação federal (Brasil, 1965; 2002; 2012) e considerando as particularidades de cada nascente selecionada. Parte-se, portanto, do pressuposto de que as nascentes não são feições pontuais, fixas e com um comportamento regular no tempo e espaço, de modo a elucidar as dificuldades de determinação das APP.

Os procedimentos de mapeamento foram realizados por meio dos softwares ArcGIS 9.3 e Google Earth. Foram produzidas representações cartográficas conforme as indicações legais, que considerassem os $50 \mathrm{~m}$ de raio ao redor das nascentes, gerados a partir de buffers com a referida equidistância, e, também, os $50 \mathrm{~m}$ de raio ao redor das nascentes com acréscimo da bacia de contribuição, gerada pela união do buffer com a delimitação manual dos interflúvios.

Adicionalmente, foram elaborados mapeamentos que consistem em propostas advindas da interpretação das incoerências e/ou impossibilidades resultantes da aplicação da lei, com base nos conceitos acadêmicos de nascentes. Essas propostas foram divididas em ideais (que considera a máxima área de proteção possível para as nascentes) e operacionais (uma adaptação pragmática dos preceitos legais sem ignorar as características de cada nascente). 
Os mapeamentos que contemplam os $50 \mathrm{~m}$ de buffer consideram a Lei n. 12.651/2012 (Brasil, 2012). Entretanto, quando inserida a noção de bacia hidrográfica contribuinte, recorre-se à Resolução CONAMA n. 303/2002 (Brasil, 2002), que regulamenta a aplicação da Lei n. 4.771/1965. Desse modo, utiliza-se a representação espacial e as características advindas dos conhecimentos científicos sobre a temática para a identificação de problemas na legislação.

A limitação encontrada no momento da delimitação da bacia hidrográfica contribuinte diz respeito à insuficiência das curvas de nível disponíveis para definir os interflúvios. Por esse motivo, utilizou-se o software Google Earth, que possui o recurso de visualização do terreno, como uma alternativa economicamente viável, uma vez que o mapeamento dessas microbacias não foi realizado em campo.

Foram obtidas imagens no software Google Earth para cada apresentação gráfica das nascentes e, para todas elas, foi mantida a mesma altitude do ponto de visão. Essas imagens foram exportadas com alta resolução e georreferenciadas no ArcGIS, no sistema de coordenadas geográficas e datum WGS84, para que a ocorrência dos erros inerentes à junção de diversas imagens no Google Earth fosse minimizada.

Em que pese a desvantagem da imprecisão cartográfica desses procedimentos, destaca-se a gratuidade dos dados fornecidos pelo Google Earth, visto que em muitos casos não se dispõe de recursos para mapear com precisão a bacia de contribuição de uma nascente, a qual pode variar de poucos $\mathrm{m}^{2}$ a $\mathrm{km}^{2}$. Para casos em que haja a necessidade de maior precisão cartográfica, o mapeamento pode ser feito em campo com o auxílio de ferramentas geodésicas ou topográficas. Todavia, para os objetivos propostos neste trabalho, consideram-se os procedimentos satisfatórios, já que é elaborada uma representação ilustrativa das nascentes e suas respectivas APP, não havendo o intuito da precisão do mapeamento.

\section{Legislação de proteção às nascentes}

O reconhecimento das nascentes pelas leis ambientais brasileiras é dúbio: se por um lado elas são assíduas nos textos legais, com reconhecida importância ambiental, por outro, a falta de conhecimento científico dificulta a efetivação e a instauração de leis mais abrangentes com relação à dinâmica das nascentes. Segundo Miranda (2011, p. 99), as mudanças 
que foram feitas no Código Florestal de 1965 "emergem no contexto da busca pela ampliação da capacidade produtiva da economia brasileira, principalmente no tocante à produção agrícola”. Ainda segundo o autor, há estratégias de dominação ideológica, de forma que as concessões são inevitáveis diante do cenário de expansão econômica do país (Miranda, 2011). Nesse sentido, as Reservas Legais e as Áreas de Preservação Permanente assumem papel de destaque quanto à proteção ambiental, de maneira que a manutenção da água _ recurso hídrico de qualidade e quantidade suficiente para o abastecimento humano _ está relacionada, em parte, à proteção das nascentes dos cursos d'água e da vegetação a elas associadas. Segundo a Lei Federal n. 12.651, de 25/5/2012, são consideradas Áreas de Preservação Permanente (APP) "as áreas no entorno das nascentes e dos olhos d'água perenes, qualquer que seja sua situação topográfica, no raio mínimo de 50 (cinquenta) metros" (Brasil, 2012; Art. $4^{\circ}$, IV). Essa diretriz não mudou o raio de proteção previsto na Lei Federal n. 4.771, de 15/09/1965, porém alterou conceitualmente a definição, já que considera apenas as nascentes perenes, ignorando a possibilidade de intermitência.

Como resultado, independentemente das características das nascentes perenes, deveria ser atribuída uma equidistância de $50 \mathrm{~m}$ a partir do local de exfiltração da água subterrânea. Com o passar dos anos, esse critério (referido na Lei n. 4.771/1965) foi amplamente aplicado em estudos acadêmicos e de licenciamento ambiental, sobretudo após a universalização de técnicas de cartografia digital e geoprocessamento. Sua simplicidade e seu pragmatismo facilitaram o seu emprego. Entretanto, quando a intenção é manter a quantidade de água, a preservação dos $50 \mathrm{~m}$ é irrelevante diante da falta de proteção das áreas de recarga dos aquíferos (Valente; Gomes, 2005).

Posteriormente, a Lei n. 4.771/1965 foi regulamentada pela Resolução CONAMA n. 303/2002, que estabeleceu um conceito jurídico para nascentes, com o propósito de balizar a identificação desses sistemas e a delimitação das APP, uma vez que isso não havia sido feito anteriormente. Segundo a Resolução, nascente ou olho d'água é o "local onde aflora naturalmente, mesmo que de forma intermitente, a água subterrânea” (Brasil, 2002, Art. $2^{\circ}$ ).

A Resolução CONAMA n. 303/2002 complementou a definição de APP presente na Lei n. 4.771/1965, conferindo uma dimensão espacial: 
"ao redor de nascente ou olho d'água, ainda que intermitente, com raio mínimo de cinquenta metros, de tal forma que proteja, em cada caso, a bacia hidrográfica contribuinte" (Brasil, 2002, Art. $2^{\circ}$ ). Apresenta--se, assim, um elemento novo e importante quando se trata da proteção das nascentes: a possibilidade de incluir a bacia de contribuição nos mapeamentos de APP. Nesse caso, há uma singela discordância entre os marcos legais, pois o antigo Código Florestal de 1965 e a Lei n. 12.651/2012 não citam a bacia hidrográfica contribuinte.

Com a entrada em vigor do novo Código Florestal - Lei n. 12.651/2012 -, alterou- -se o conceito jurídico de nascente, excluindo a possibilidade de intermitência. Segundo a Lei, nascente é um "afloramento natural do lençol freático que apresenta perenidade e dá início a um curso d'água" (Brasil, 2012, Art. 3․, XVII) e olho d'água é o "afloramento natural do lençol freático, mesmo que intermitente” (Brasil, 2012, Art. $3^{\circ}$, XVIII).

Na prática, as nascentes intermitentes (ou seja, os olhos d'água, segundo a legislação em vigor) são colocadas em segundo plano, não sendo prevista qualquer proteção especial para esses sistemas, excetuando-se a já prevista para os cursos d'água. Nascentes intermitentes possuem uma dependência mais pronunciada das águas meteóricas, porém, após um intervalo de meses, semanas ou dias de estiagem, a sua exfiltração passa a ser relevante para a contribuição da vazão afluente aos cursos d'água. Diante da fragilidade das nascentes, consideradas como sistemas ambientais sujeitos a diversas perturbações, a proteção da bacia hidrográfica contribuinte torna ainda mais complexa a definição das APP. Ademais, consta na Lei n. 4.771/1965 que, para as áreas urbanas, devem ser observados os respectivos planos diretores e as leis de uso do solo (Brasil, 1965, Art. $2^{\circ}$, Parágrafo Único). A Lei n. 12.651/2012 soluciona esse impasse ao exigir o respeito das APP de nascentes mesmo que em área urbana, excetuando-se os casos de "interesse social” (Brasil, 2012, Art. 2º, IX).

A partir desses desafios conceituais, observa-se que o mapeamento das APP de nascentes atualmente é realizado, de um modo geral, na forma de um buffer de 50 metros do local de exfiltração no momento da visita e ocultando as especificidades da dinâmica de cada nascente.

Percebe-se que, para os casos de nascentes com exfiltração difusa ou múltipla, nascentes intermitentes ou nascentes móveis, há um problema conceitual não abarcado pela legislação ambiental em vigor, a qual se baseia em um padrão tradicional de nascentes pontuais, perenes e fixas que podem não ser as mais corriqueiras em determinados ambientes. 
Estudos de caso: ilustrando a necessidade de aproximação entre critérios legais e científicos na concepção de nascentes

As nascentes estudadas estão situadas em contextos representativos de três grandes unidades geomorfológicas e em unidades de conservação de proteção integral de âmbito municipal e federal. Enquanto a nascente N065 está no contexto da Depressão de Belo Horizonte (IBGE, 2006), a N005 e a N018 estão situadas na borda norte da Serra do Curral, que marca o limite norte das Serras do Quadrilátero Ferrífero (IBGE, 2006). A Figura 1 apresenta a localização destas nascentes no município de Belo Horizonte e em suas respectivas unidades de conservação.

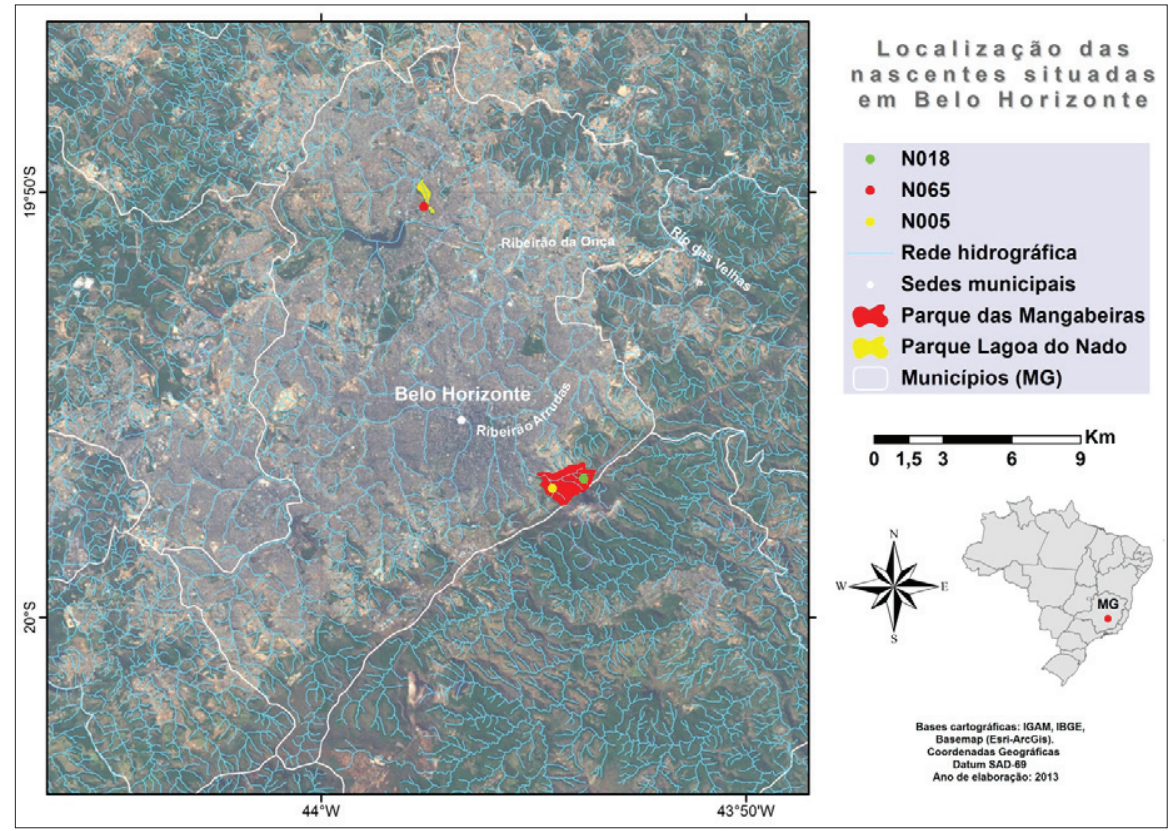

Figura 1 - Localização das nascentes N065, N005 e N018 no município de Belo Horizonte.

Já a SC24 está situada na Serra do Cipó, sendo esta parte do alinhamento de serras a que se confere a denominação geral de Serras do Espinhaço Meridional (IBGE, 2006). A Figura 2 apresenta a localização desta nascente no contexto do Parque Nacional da Serra do Cipó. 


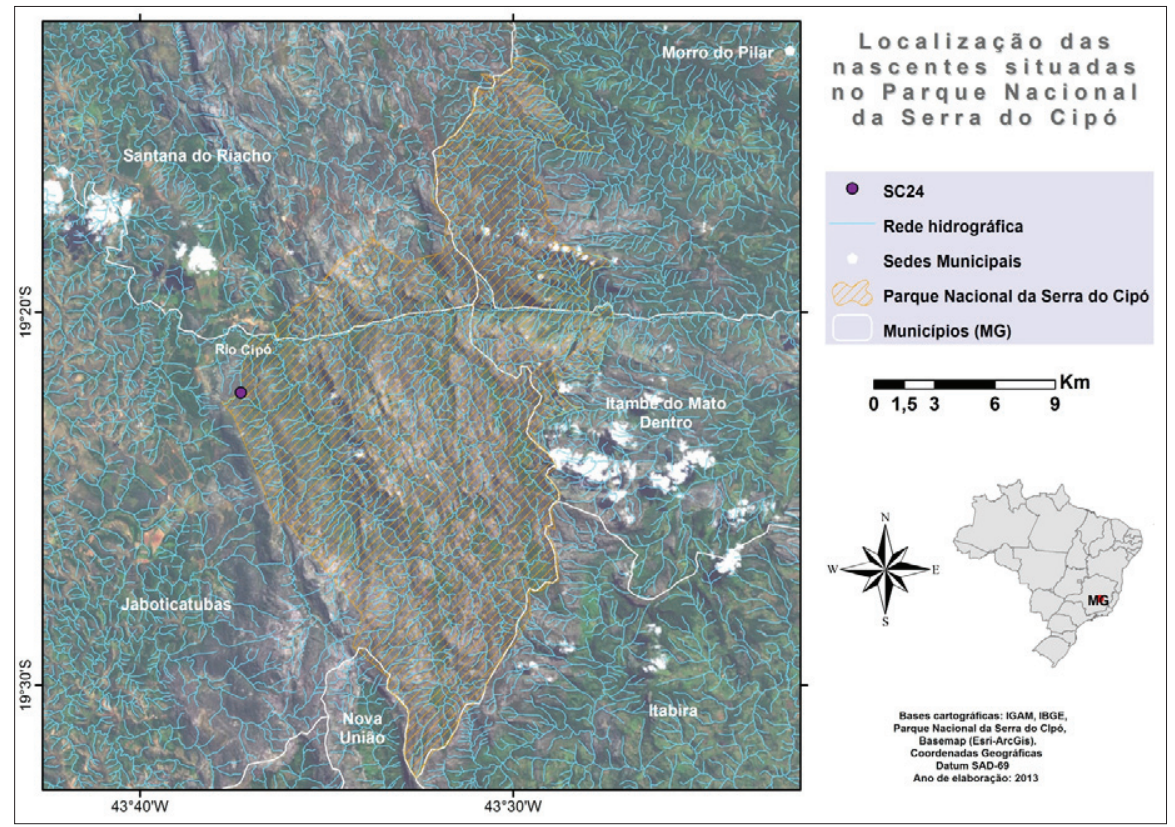

Figura 2 - Localização da nascente SC24 no Parque Nacional da Serra do Cipó.

Esses três grandes domínios geomorfológicos correspondem a conjuntos geológicos específicos. A Depressão de Belo Horizonte está esculpida sobre rochas do Embasamento Cristalino Arqueano do Complexo Belo Horizonte. As nascentes do Quadrilátero Ferrífero se configuram nas sequências metamórficas paleoproterozoicas do Supergrupo Minas. E, finalmente, as nascentes da Serra do Cipó ocorrem nas rochas do Grupo Macaúbas. As bacias hidrográficas das quais as nascentes fazem parte são integrantes da bacia do Rio das Velhas, afluente do rio São Francisco (CPRM, 2004).

A nascente N005 (Figura 3-A) possui exfiltração pontual e perene, representando o padrão clássico previsto pela legislação, com uma feição muito bem marcada na superfície e com uma vazão superior a $1 \mathrm{~L} / \mathrm{s}$, relativamente constante ao longo do ano hidrológico. Essa nascente é marcada por fluxos de acentuada energia, o que resulta em um canal muito bem definido, denotando a capacidade erosiva do sistema. Possui morfologia em duto que, em geral, está associada às exfiltrações pontuais (Felippe, 2009). Também podem ser observados afloramentos rochosos próximos à nascente, relativos ao substrato itabirítico da Formação Cercadinho. 


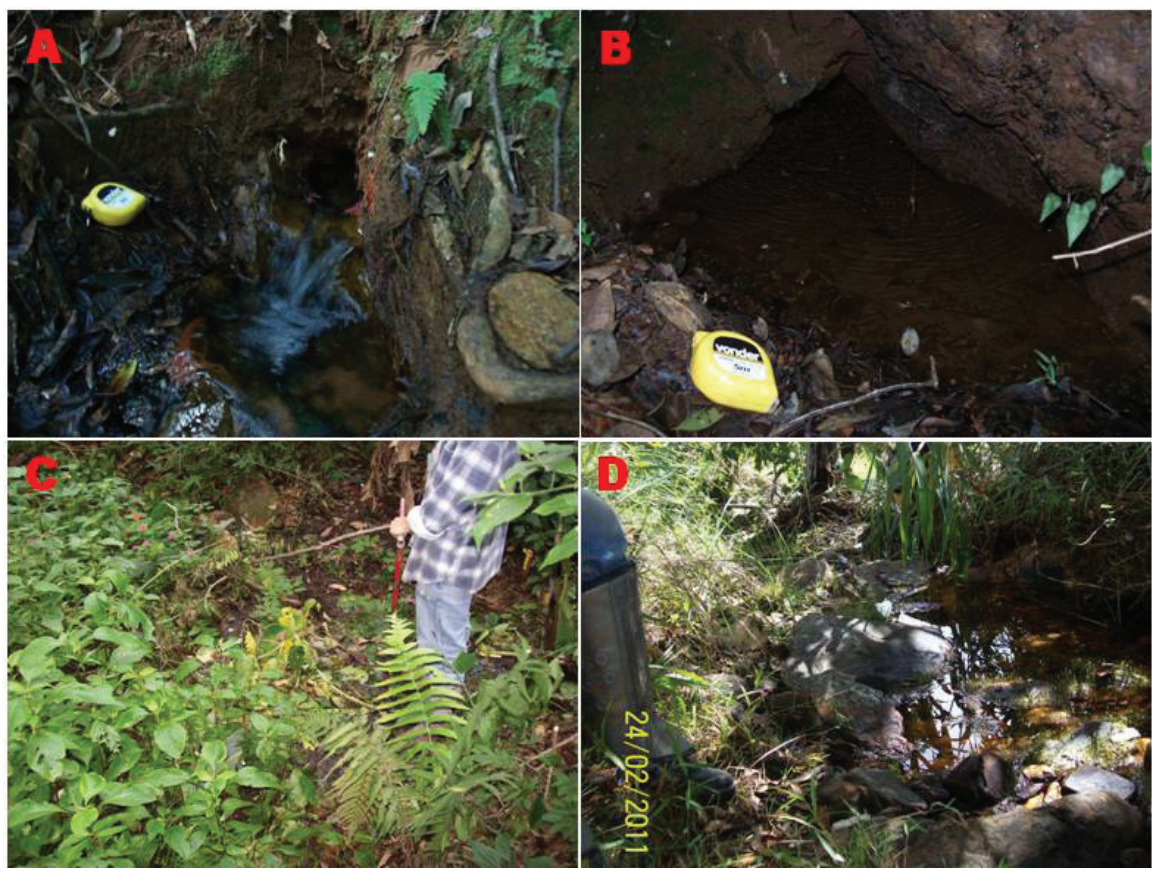

Figura 3 - Fotografias das nascentes em estudo: A) N005; B) N018; C) N065; D) SC24.

A nascente N018 (Figura 3-B) é pontual e intermitente. Está situada em um talvegue gerado pelo escoamento superficial concentrado e a exfiltração da água está condicionada pelo afloramento rochoso da Formação Gandarela, que reduz a velocidade do fluxo de base e conduz a água para a superfície, em um ambiente onde a recarga ocorre sobre solos rasos e rochas fraturadas (Felippe, 2009). Nesse sentido, a característica de intermitência da exfiltração está diretamente relacionada à rápida resposta do aquífero diante da ocorrência dos eventos de precipitação, obtendo vazões consideráveis no período de chuva e de descarga da água circulante no aquífero. Contudo, não há capacidade de armazenamento suficiente para sustentar a exfiltração no período com ausência de chuvas, cessando a drenagem superficial.

A nascente N065 (Figura 3-C) apresenta exfiltração difusa e morfologia do tipo concavidade. Ressalta-se que esse é o padrão mais comum encontrado na Depressão de Belo Horizonte (Felippe, 2009). No caso da N065, isso pode ser explicado pelo baixo gradiente topográfico, levando em consideração a amplitude altimétrica da bacia. Assim, a baixa declivi- 
dade associada a um espesso manto de intemperismo favorece a desconcentração dos fluxos, caracterizando um ambiente de baixa energia de circulação da água. Como resultado, é gerada uma extensa área encharcada na qual ocorre a exfiltração, com limites variáveis ao longo do ano (efeito da precipitação). Na abordagem desse tipo de nascente, para mapeamento de APP, destaca-se a necessidade de demarcar os limites aproximados da área de exfiltração (zona brejosa).

A nascente SC24 (Figura 3-D) está situada na Serra do Cipó e é a nascente primária da bacia do Córrego da Serra, afluente da margem direita do rio Cipó. Está localizada em substrato predominantemente quartzítico do Grupo Macaúbas e apresenta morfologia do tipo talvegue, com exfiltração múltipla. Contudo, a principal característica da nascente é a mobilidade ao longo da vertente, que varia de acordo com a sazonalidade. Durante os meses de monitoramento, notou-se que, do ponto mais alto, identificado no auge do período úmido, ao ponto mais baixo, identificado no auge do período da seca, há uma distância de migração de aproximadamente 1,5km.

\section{Mapeamentos de APP de nascentes: propostas de critérios ideais e operacionais}

A partir da caracterização das nascentes, foi possível realizar dois mapeamentos: a) contemplando as possíveis APP previstas na legislação, ou seja, com os 50 m de raio, que não mudaram na Lei n. 12.651/2012; b) contemplando as bacias de contribuição das nascentes, previstas na Resolução CONAMA n. 303/2002, que regulamentou o antigo Código Florestal. Para ambos, foram concebidas propostas sobre o quadro operacional e o cenário considerado ideal quanto aos processos de mapeamento de APP de nascentes no país. As propostas foram apresentadas em conjunto para facilitar a interpretação.

Como operacional foi considerada a proposta de mapeamento de APP que fosse condizente com a realidade brasileira, não sendo necessária uma grande mudança nos textos legais, para que, porventura, possam ser incluídas nas medidas de proteção as características factuais das nascentes. O que foi chamado de quadro ideal refere-se à estratégia de mapeamento que representaria maior potencial de proteção às nascentes. Para ambas as propostas, destaca-se a necessidade de dois períodos de monitoramento para a identificação do comportamento sazonal aproximado de cada nascente, o que permite o levantamento da intermitência, a mobilidade e as variações no tipo da exfiltração. 
A proteção da bacia de contribuição favorece a abordagem das nascentes como sistemas, uma vez que, em seu entorno, encontram-se todos os elementos citados na legislação como passíveis de proteção integral sob a forma das APP. Esses elementos têm papel ambiental importante para "preservar os recursos hídricos, a paisagem, a estabilidade geológica e a biodiversidade, facilitar o fluxo gênico de fauna e flora, proteger o solo e assegurar o bem-estar das populações humanas" (Brasil, 2012, Art. 3º, II).

O Quadro 1 sintetiza as mudanças que a Lei n. 12.651/2012 trouxe com relação às nascentes, ilustrando a aplicação para o caso de cada nascente em estudo, além de apresentar as propostas de solução operacional e ideal.

Quadro 1 - Síntese das implicações da Lei n. 12.651/2012 nas nascentes estudadas e as respectivas propostas operacional e ideal.

\begin{tabular}{|c|c|c|c|c|}
\hline Nascente & Características & $\begin{array}{l}\text { Implicação do } \\
\text { novo código }\end{array}$ & $\begin{array}{l}\text { Proposta } \\
\text { operacional }\end{array}$ & Proposta ideal \\
\hline N005 & $\begin{array}{l}\text { Exfiltração } \\
\text { pontual e } \\
\text { perene, com } \\
\text { morfologia do } \\
\text { tipo duto. }\end{array}$ & $\begin{array}{l}\text { Nascentes } \\
\text { semelhantes } \\
\text { continuarão a } \\
\text { representar o padrão } \\
\text { idealizado tanto pela } \\
\text { legislação quanto } \\
\text { pelo próprio senso } \\
\text { comum. }\end{array}$ & $\begin{array}{l}\text { Proteção mínima } \\
\text { dos } 50 \mathrm{~m} \text { de } \\
\text { raio ao redor da } \\
\text { nascente. }\end{array}$ & $\begin{array}{l}\text { Proteção da bacia } \\
\text { de contribuição, } \\
\text { considerando os } \\
50 \text { m mínimos de } \\
\text { raio. }\end{array}$ \\
\hline N018 & $\begin{array}{l}\text { Exfiltração } \\
\text { pontual e } \\
\text { intermitente, } \\
\text { com morfologia } \\
\text { do tipo talvegue. }\end{array}$ & $\begin{array}{l}\text { Nascentes como } \\
\text { essa passam a ser } \\
\text { consideradas “olhos } \\
\text { d'água” e não contam } \\
\text { com APP. }\end{array}$ & $\begin{array}{l}\text { Proteção mínima } \\
\text { dos } 50 \text { m de } \\
\text { raio ao redor da } \\
\text { nascente. }\end{array}$ & $\begin{array}{l}\text { Proteção da bacia } \\
\text { de contribuição, } \\
\text { considerando os } \\
50 \text { m mínimos de } \\
\text { raio. }\end{array}$ \\
\hline N065 & $\begin{array}{l}\text { Exfiltração } \\
\text { perene e difusa, } \\
\text { com morfologia } \\
\text { do tipo } \\
\text { concavidade. }\end{array}$ & $\begin{array}{l}\text { Nascentes } \\
\text { semelhantes } \\
\text { continuam com } \\
\text { o problema da } \\
\text { interpretação pontual, } \\
\text { o que significa } \\
\text { perdas de área total } \\
\text { protegida. }\end{array}$ & $\begin{array}{l}\text { Proteção mínima } \\
\text { dos } 50 \text { m de } \\
\text { raio a contar } \\
\text { com base na } \\
\text { área média de } \\
\text { exfiltração, } \\
\text { considerando } \\
\text { verão/inverno. }\end{array}$ & $\begin{array}{l}\text { Proteção da bacia } \\
\text { de contribuição, } \\
\text { considerando os } \\
50 \text { m mínimos } \\
\text { de raio a partir } \\
\text { da área máxima } \\
\text { de exfiltração } \\
\text { (verão). }\end{array}$ \\
\hline SC24 & $\begin{array}{l}\text { Exfiltração } \\
\text { perene e } \\
\text { múltipla, com } \\
\text { morfologia do } \\
\text { tipo talvegue. } \\
\text { Apresenta } \\
\text { característica de } \\
\text { mobilidade. }\end{array}$ & $\begin{array}{l}\text { Nascentes } \\
\text { semelhantes a essa } \\
\text { mantêm o problema } \\
\text { de as características } \\
\text { de mobilidade } \\
\text { e de exfiltração } \\
\text { múltipla não serem } \\
\text { consideradas no texto } \\
\text { legal. }\end{array}$ & $\begin{array}{l}\text { Proteção mínima } \\
\text { dos } 50 \mathrm{~m} \text { de raio } \\
\text { a contar da linha } \\
\text { que demarca } \\
\text { a trajetória da } \\
\text { nascente entre o } \\
\text { auge do inverno } \\
\text { e o do verão. }\end{array}$ & $\begin{array}{l}\text { Proteção da bacia } \\
\text { de contribuição, } \\
\text { considerando os } \\
50 \mathrm{~m} \text { mínimos } \\
\text { de raio, a } \\
\text { contar do ponto } \\
\text { mais a jusante } \\
\text { identificado. }\end{array}$ \\
\hline
\end{tabular}


A nascente N005 possui o mapeamento convencional (Figura 4), de modo que a proteção de $50 \mathrm{~m}$ de raio torna-se a própria solução operacional. Contudo, a bacia de contribuição assume uma relevância maior de proteção quando acrescida ao buffer de $50 \mathrm{~m}$.

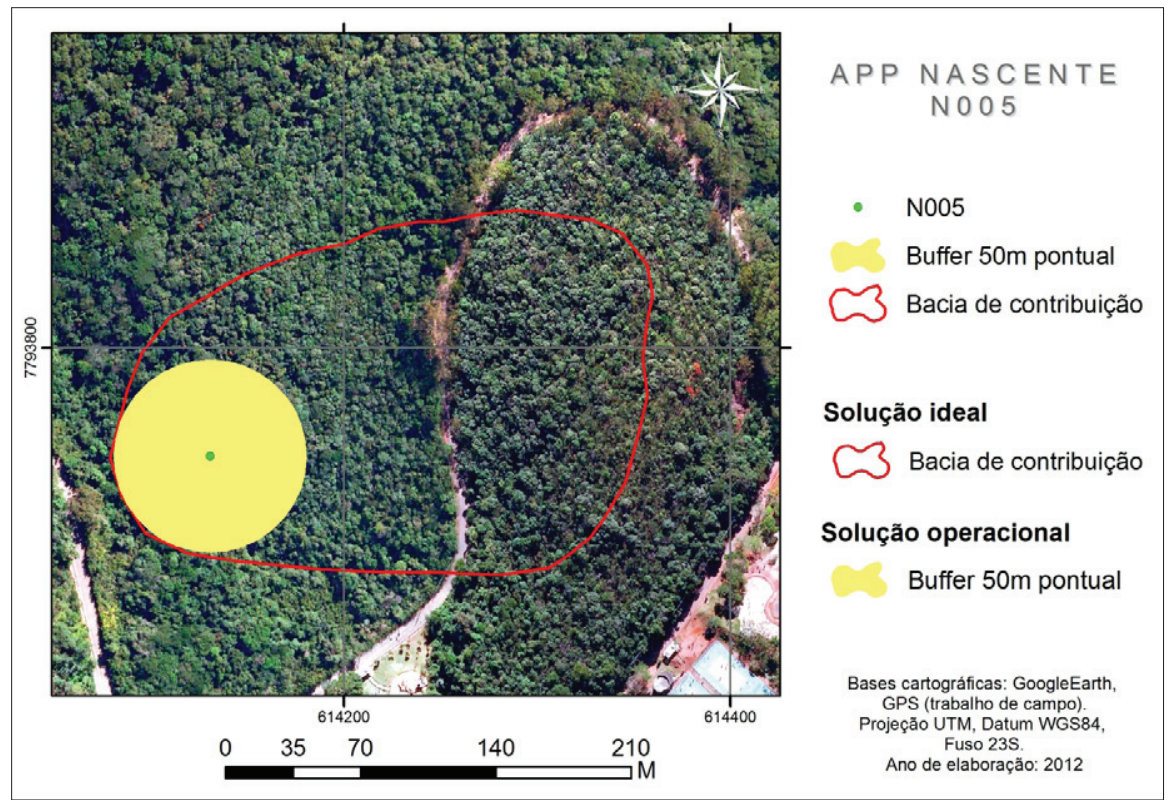

Figura 4 - Representação gráfica das possibilidades de APP para a nascente N005.

No caso da SC24 (Figura 5), não foi identificado nenhum aspecto nos textos legais que prevê o seu comportamento migratório ao longo do ano. Contudo, se a oscilação do nível freático é um fenômeno por ora bem conhecido, a oscilação do ponto de exfiltração, ou seja, do posicionamento da nascente, também é algo esperado. A única alternativa seria mapear a nascente nos dois períodos (seco e úmido). Os atuais $50 \mathrm{~m}$ de raio a partir de um ponto arbitrário são pouco significativos diante da dinâmica de mobilidade e de surgimento e ressurgimento do posicionamento dos pontos de exfiltração. Apesar da condição de transitoriedade, é possível estabelecer uma proposta operacional. Assim, considera-se que proteger a linha da trajetória na qual a nascente migra - considerando o seu ponto de exfiltração mais a montante e o mais a jusante com um buffer de $50 \mathrm{~m}$ - 
confere uma proteção mais eficaz e que considera a dinâmica da nascente. A delimitação em torno de pontos isolados de monitoramento não é ideal, uma vez que a tendência observada in loco é que a exfiltração não ocorre exatamente no mesmo local. A solução ideal abarca delimitar a bacia de contribuição considerando o buffer de $50 \mathrm{~m}$ delimitado para o ponto de exfiltração identificado mais a jusante.

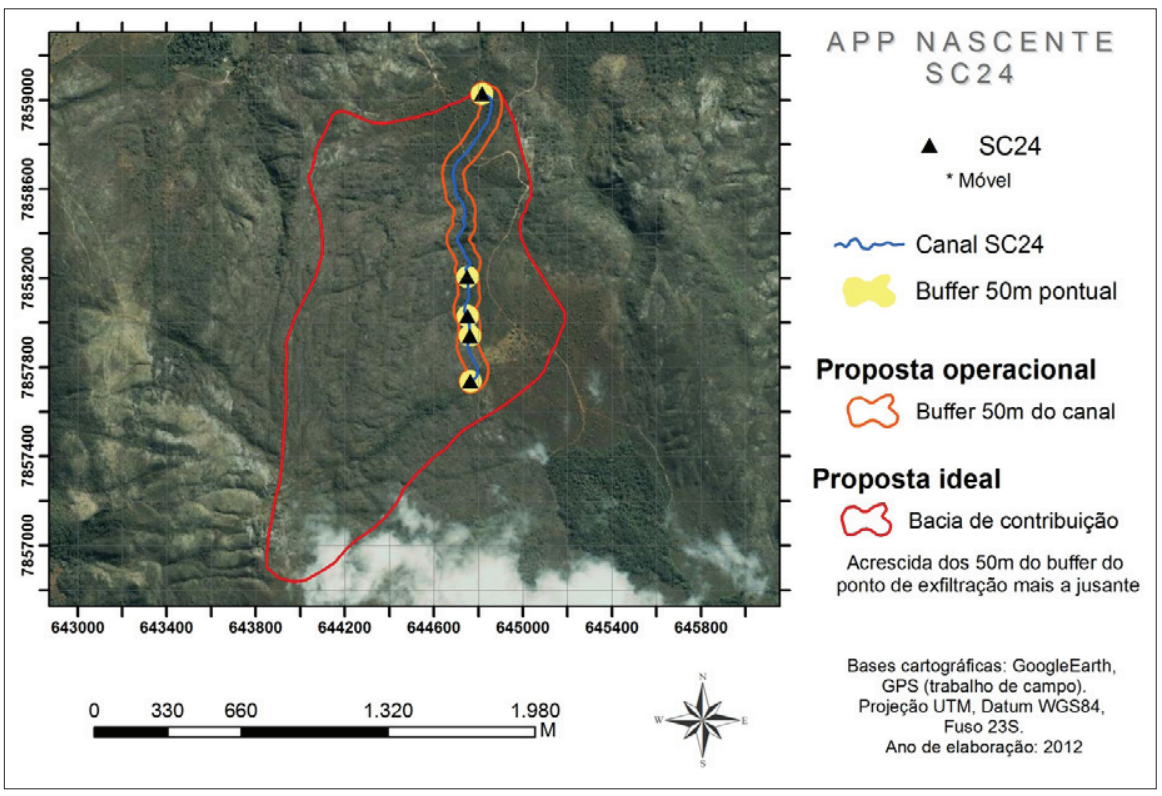

Figura 5 - Representação gráfica das possibilidades de APP para a nascente SC24.

A nascente N065 (Figura 6) apresenta exfiltração difusa em uma extensa área brejosa. Apesar de convencionalmente ser tomado um ponto central arbitrário para a localização da nascente, recomenda-se a medição e o mapeamento da área de exfiltração em campo para a posterior definição da APP. Assim, como proposta operacional, os $50 \mathrm{~m}$ de raio devem ser obtidos com base no perímetro médio da área inundada entre o período de máxima umidade e máxima seca. A proposta ideal é que a APP seja demarcada a partir da junção de um buffer de 50 m da máxima área saturada (verão) com a bacia de contribuição. 


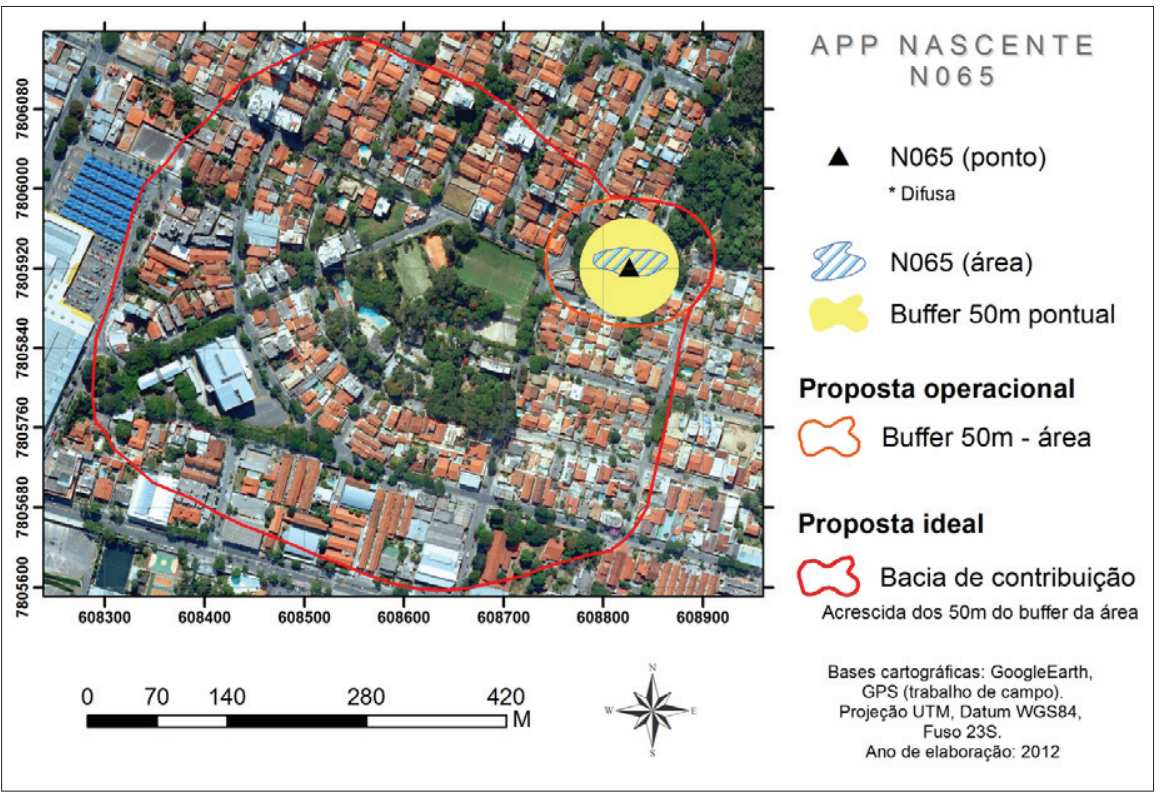

Figura 6 - Representação gráfica das possibilidades de APP para a nascente N065.

Complementando os casos discutidos, a nascente N018 pode ser classificada como olho d'água, conforme a nova Lei, o que elimina a obrigatoriedade de uma APP em seu entorno. Porém, por tratar-se do início de um canal de drenagem, a nascente estaria inserida dentro da APP de margem de cursos d'água. Esta, porém, possui extensão inferior àquela prevista para as nascentes.

Reitera-se a importância de nascentes intermitentes para a dinâmica hidrológica superficial, sobretudo nos climas marcados por períodos preponderantemente secos ou chuvosos. Logo, em termos operacionais, a APP de nascentes intermitentes poderia manter os $50 \mathrm{~m}$ de raio previstos para as perenes (Figura 7). O ideal, contudo, é a proteção da bacia de contribuição, a contar a partir do buffer de $50 \mathrm{~m}$. No caso das nascentes intermitentes, a proteção da bacia de contribuição assegura a continuidade temporal dos processos de infiltração, percolação, armazenamento e exfiltração das águas pluviais, de acordo com o ritmo natural do sistema. 


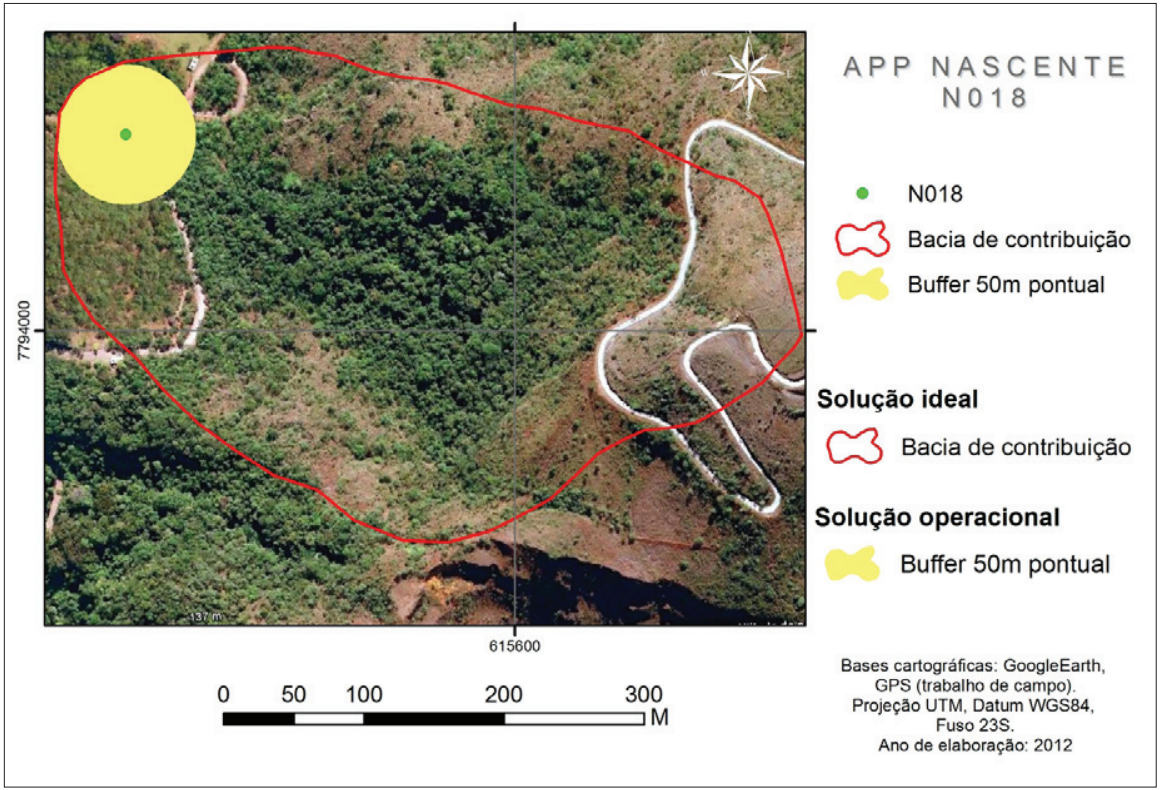

Figura 7 - Representação gráfica das possibilidades de APP para a nascente 018.

Considerações finais

As características ambientais das nascentes, observadas em campo e com o subsídio da produção científica ora disponível, demonstram que a delimitação de APP a partir de um buffer de 50 m pode não ser a solução mais adequada para garantir a proteção desses sistemas. Isso pode ser constatado com base nos exemplos selecionados para representação. Percebe-se a necessidade, em primeiro lugar, de padronização dos procedimentos utilizados para identificar as nascentes (desde o seu conceito até o seu mapeamento), de maneira que os elementos fundamentais para a proteção não sejam postos de lado pela mera consideração de $50 \mathrm{~m}$ em torno dos pontos iniciais de canais demarcados em bases hidrográficas digitais, por exemplo.

Com a finalidade de contribuir com o levantamento dos desafios, apresentou-se uma discussão sobre a legislação em vigor e fez-se um paralelo com a legislação anterior, identificando as mudanças mais relevantes quanto à proteção das nascentes.

Considera-se um equívoco a não inclusão da proteção da bacia hidrográfica contribuinte (conforme a Resolução CONAMA 303/2002) no 
texto da Lei n. 12.651/2012, de forma que as reflexões aqui realizadas indicam a necessidade de aproximação da legislação à realidade prática das nascentes, fundamentada no atual estágio de conhecimento científico sobre esses sistemas. Apesar de a legislação se basear em nascentes pontuais, perenes e fixas, não podem ser ignoradas as nascentes móveis, difusas ou mesmo intermitentes. Todas essas categorias podem ter um papel hidrológico extremamente importante para o ajuste dos sistemas fluviais ao longo do tempo, posto que não são a regularidade e a perenidade dos fluxos que determinam o equilíbrio dos cursos d'água para a configuração dos padrões fluviais. Tampouco, podem-se considerar as nascentes como sistemas homogêneos e definir suas APP sob os mesmos preceitos. Nesse aspecto, os interesses de proteção ambiental devem sobrepor-se aos interesses econômicos, e a transformação do espaço deve ser orientada com a finalidade de garantir o equilíbrio das nascentes em longo prazo.

Por fim, reafirma-se que cada nascente está situada sob um contexto singular, de maneira que a interação entre as variáveis ambientais configura um sistema complexo e único, gerando especificidades que não podem ser negligenciadas para a criação de mecanismos de gestão e planejamento mais eficazes na conservação ou preservação ambiental.

\section{Agradecimentos}

Ao Grupo de Pesquisa em Geomorfologia e Recursos Hídricos (CNPq); ao Laboratório de Geomorfologia do IGC-UFMG; ao ICMBio; ao IBAMA; à Capes e ao CNPq pelas bolsas e pelo auxílio financeiro.

\section{Referências}

ACCIOLY, I.; SÁNCHEZ, C. Antiecologismo no Congresso Nacional: o meio ambiente representado na Câmara dos Deputados e no Senado Federal. Desenvolvimento e Meio Ambiente, Paraná, n. 25, p. 97-108, jan./jun. 2012.

BRASIL. Lei n. 4.771, de 15 de setembro de 1965. Institui o Novo Código Florestal. Brasília (DF), 1965.

. Ministério do Meio Ambiente. Resolução CONAMA n. 303, de 20 de março de 2002. Dispõe sobre parâmetros, definições e limites de Áreas de Preservaçẫo Permanente. Brasília (DF), 2002.

. Lei n. 12.651, de 25 de maio de 2012. Dispõe sobre a proteção da vegetação nativa... Brasília (DF), 2012. 
CPRM. Companhia de Pesquisa de Recursos Minerais. Serviço Geológico do Brasil. Mapa geológico do Brasil ao Milionésimo. Rio de Janeiro: CPRM, 2004.

FARIA, A. P. A dinâmica de nascentes e a influência sobre os fluxos nos canais. A Água em Revista, Rio de Janeiro, v. 8, p. 74-80, 1997.

FELIPPE, M. F. Caracterização e tipologia de nascentes em unidades de conservação de Belo Horizonte (MG) com base em variáveis geomorfológicas, hidrológicas e ambientais. Dissertação (Mestrado) - Universidade Federal de Minas Gerais, Belo Horizonte, 2009.

FELIPPE, M. F.; MAGALHÃES JR., A. P.; LAVARINI, C.; PEIFER, D.; DOLABELA, D. Espacialização e caracterização das nascentes em unidades de conservação de Belo Horizonte(MG). In: XVIII SIMPÓSIO BRASILEIRO DE RECURSOS HÍDRICOS. Anais... Campo Grande (MS): ABRH, 2009.

IBGE. Instituto Brasileiro de Geografia e Estatística. Mapa de unidades de relevo do Brasil. Escala 1:5.000.000. IBGE, 2006.

MIRANDA, L. C. O “novo” Código Florestal: tensões e estratégias de interpelações discursivas. Revista Geografias, Belo Horizonte, v. 7, n. 2, p. 98-105, jul./dez. 2011.

NEVES, C. B.; CASTRO, S. S.; SANTOS, N.; BORGES, R. O. Análise das relações entre solos, relevo e a legislação ambiental para a delimitação de áreas de preservação permanente: o exemplo da Alta Bacia do Ribeirão João Leite, estado de Goiás. Revista Brasileira de Geomorfologia, v. 10, n. 1, p. 3-21, 2009.

SPRINGER, A. E.; STEVENS, L. E. Spheres of discharge of springs. Hydrogeology Journal, v. 17, p. 83-93, 2009.

VALENTE, O. F.; GOMES, M. A. Conservação de nascentes: hidrologia e manejo de bacias hidrográficas de cabeceiras. Viçosa: Aprenda Fácil, 2005. 210 p.

Laila Gonçalves do Carmo - Bacharelanda em Geografia no Instituto de Geociências da Universidade Federal de Minas Gerais, atualmente desenvolve e participa de pesquisas relativas à Geomorfologia Fluvial e nascentes, desenvolvidas no âmbito do Laboratório de Geomorfologia e Recursos Hídricos do Instituto de Geociências da mesma Universidade.

Miguel Fernandes Felippe - Graduado e Mestre em Geografia pela Universidade Federal de Minas Gerais, Doutor em Análise Ambiental pela mesma Universidade, Professor do Departamento de Geociências da Universidade Federal de Juiz de Fora.

Antônio Pereira Magalhães Junior - Graduado em Geografia pela Universidade Federal de Minas Gerais, Mestre em Geografia e Análise Ambiental pela mesma Universidade, Doutor em Desenvolvimento Sustentável pela Universidade de Brasília, Professor da Universidade Federal de Minas Gerais. 